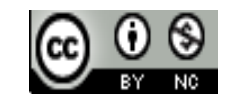

Journal of Education, Teaching, and Learning is licensed under

A Creative Commons Attribution-NonCommercial 4.0 International License.

\title{
NARRATIVE STRUCTURE OF THE $N$ ' B BARAKNG KULUP STORY ORAL Literature OF DAYAK KANAYATN: A STUDY OF ACTANTIAL A.J. GREIMAS
}

\author{
Sesilia Seli ${ }^{1)}$, Antonius Totok Priyadi ${ }^{2)}$, Sisilya Saman ${ }^{3)}$, Laurensius Salem ${ }^{4)}$ \\ ${ }^{1)}$ Universitas Tanjungpura, Pontianak, Indonesia \\ E-mail: sesilia.seli@fkip.untan.ac.id \\ ${ }^{2)}$ Universitas Tanjungpura, Pontianak, Indonesia \\ E-mail: antonius.totok.priyadi@fkip.untan.ac.id \\ ${ }^{3)}$ Universitas Tanjungpura, Pontianak, Indonesia \\ E-mail: sisilya.saman.madeten@fkip.untan.ac.id \\ ${ }^{4)}$ Universitas Tanjungpura, Pontianak, Indonesia \\ E-mail: laurensius.salem@fkip.untan.ac.id
}

\begin{abstract}
This study is based on the importance of conducting an in-depth study of the characters of Ne' Baruakng Kulup story of Dayak Kanayatn's oral literature. This story narrates an attempt made by Baruakng to bring paddy into the earth which was full of obstacles so that he was named $N e$ ' Baruakng Kulup. The aims of this study to describe the actantial schemes and functional structures in the Ne' Baruakng Kulup story. The life dynamic of Baruakng is interesting to study more in-depth by using the study of narrative structure based on the thinking of A.J. Greimas. This qualitative study was focused on two important elements, namely: (1) the actantial scheme in the story of Ne' Baruakng Kulup; and (2) the functional structure in the story of Ne' Baruakng Kulup. The techniques of collecting data in this study were a documentary study and analyzed using structural approaches. The results of this study indicate that there are 14 actantial schemes and 14 functional structures. Four actant schemes and 4 perfect functional structures and 10 actantial schemes, and 10 imperfect functional structures. The main actantial scheme lies in the sixth actant scheme. There is a correlational relationship between the actant scheme and the functional structure. The character of Ne' Baruakng Kulup is a hero in the story analyzed.
\end{abstract}

Keywords: Narrative Structure; Actantial Study; Oral Literature; Dayak Kanayatn

\section{INTRODUCTION}

This research is based on the importance of conducting an in-depth study of the character of $\mathrm{Ne}$ ' Baruakng Kulup, a story of Dayak Kanayatn oral literature. This story is about the descent of paddy to earth brought by a Baruakng from Kayangan, a land of heaven, due to his concern for humans. As a result of his action, he finally settled on earth. It is said that his life journey was full of adventure with various obstacles he faced, including his marriage to three wives who came from three different types of creatures such as a human, a fairy and a ghost.
As a legend, this tale is believed by the Dayak Kanayatn community as a life story based on a true story. In the story of $\mathrm{Ne}^{\prime}$ Baruakng Kulup, some traditional practices can be found such as agricultural tradition, traditional medicine or healing, traditional ceremonies, circumcision tradition, and Bapangka tradition or the tradition of playing Spinning Top, Pengayau or cutting off enemy heads in war. Not to mention, methods to use nature universe that is rich with biodiversity resources wisely.

The story of Ne' Baruakng Kulup which was initially in oral form has been documented, and there have been many writings and research conducted by writers on this story. 
Nevertheless, for the authors, the tale of $N e^{\prime}$ Baruakng Kulup remains interesting to study further, so that there will be a wide variety of study findings resulted from study models which are different from the previous studies.

In this time research, the focus was on the main character of the story, namely Baruakng. Besides being known as a legendary figure who is kind and generous, Baruakng has a historical connection with the origin of paddy and the tradition of agriculture in the Dayak Kanayatn community. To be able to grasp the essential meaning and to understand the structure of the story well, the authors chose an Actantial study that more exploits the existence of the character and his involvement in various events. As stated by Greimas (Luxemburg et al., 2009), the relationship that occurs between actors (actans) in a story can explain the existing functional relationships. To well understand the functional relationships and to provide a more detailed understanding, Actantial theory and functional models developed by Greimas were used in this study.

In addition to analysing the narrative structure of the $N e$ ' Baruakng Kulup story, this research was also intended to prepare a lecture plan for the Prose Study course based on the results of this research. The preparation of the Lecture plan is intended to aid lecturers as well as students to implement various approaches in studying local literature, especially by using the structural (objective) approach based on the theory of A.J. Greimas. Thus, the results of this study can be used as an example in analyzing folklore as a product of regional literature.

Problems in this study include (1) what are the actant schemes in the story of Ne' Baruakng Kulup? and (2) what are functional models in the story of Ne' Baruakng Kulup?. The objectives of this study are as follows: (1) to describe the results of analysis and interpretation of the actantial schemes in the Ne' Baruakng Kulup story and (2) to describe the results of analysis and interpretation of the functional structures in the Ne' Baruakng Kulup story.

\section{LITERATURE REVIEW}

Theoretically, this research is useful for implementing the theory of the narrative structure of A.J. Greimas as well as enriching the knowledge of the elements contained in the actant schemes and functional structures in folklore. Therefore, practically the benefits of this study are as follows.

1. The analysis model of A.J. Greimas can be used to analyze folklore.

2. The texts of Ne' Baruakng Kulup can be used as a study corpus for other researchers interested in researching it from different aspects both in the field of linguistics and literature.

3. The texts of $N e^{\prime}$ Baruakng Kulup can function as a data source in the practice of analyzing folklore.

4. The texts of Ne' Baruakng Kulup can be used as localcontent texts related to local/regional literature.

5. The theories used include folklore, structuralism, narratology, and actantial of A.J. Greimas.
Folklore is generally in the form of oral literature and is part of oral tradition. Francis Lee Utley (Dundes, 1965) calls this term literature transmitted orally or unwritten literature. According to Hutomo (1991), oral literature is literature that includes the expression of literary works in a culture that is spread and passed down orally (word of mouth). As part of oral literature, folklore is seen as a social document because it contains various social problems that occur in the community of its owner.

Damono also reveals that literature is the crystallization of beliefs, values, and norms agreed upon by society. That is what happened in the past that oral literature was shared by the community (Escarpit, 2005). Besides, literature displays images of life and life itself is the social reality. In this sense, life encompasses the relationship between society and society, between society and individuals, between humans and humans, and between events and events that occur within one's inner mind of selfhood. Literature must be seen as something related to and inseparable from people's lives, background elements of history and social elements that influence it (Escarpit, 2005).

Folktale is part of folklore. Brundvand (1968) differentiates the folklore genre into three major groups, namely: (1) verbal folklore; (2) partly-verbal folklore; and (3) nonverbal folklore. Verbal folklore is a folktale in an oral form and is descended orally by word of mouth. The folk tale is included in verbal folklore. As part of verbal folklore, the spread of folktales is done orally by word of mouth.

Dayak Kanayatn folktales can be grouped into myths, legends, and fables. According to Eliade (1964), myth narrates a sacred history; it relates an event that took place in primordial times the fabled time of the "beginnings". In other words, the myth tells how, through the deeds of supernatural beings, a reality come into existence, be it the whole of reality, the cosmos, or only a fragment of realityan island, a species of plant, a particular kind of human behaviour, an institution.

Legend is one of the genres of folklore that is seen as an ancient legacy that can be used to convey a more genuine superstition and attitude towards us (Krohn, 1971). Stories categorized into legend include things that are extraordinary and considered true by their supporters (Dorson, 1968), even legends are seen as historical events said by Hutomo (1991) as the folk history so that they are believed to be true. Legend serves to educate and equip humans, especially the owner community to avoid danger.

In contrast to myths and legends, fairy tales are folk tales that describe people's lives or people's dreams of a better life. Fairy tales are not considered to be truly happening, they are mere fiction, but are very useful to educate people and lead them in a better direction.

Myth, legend, and fairy tale are still existing today in the Dayak Kanayatn community, where some of their inheritance is still carried out verbally. Folk stories are not just stories, but stories that contain moral teachings, describe the culture of the community in the past, reflect the customs adhered to by the Dayak Kanayatn community. They are 
also used to educate, inherit and validate the enactment of cultural values and customs, and it functions to entertain.

According to Emzir and Rohman (2016), narratology is the science of stories. Narration comes from Latin, meaning stories, words, stories, saga, and logos means knowledge. In the story are natural elements found and called events. The events connected are called a plot. Sehandi (2014) says that the purpose of narrative theory is to analyze or examine literary works in the form of narration or discourse. In general, the theory of narratology cannot be separated from other literary theories, because other literary theories, both those included in the groups of structuralism and poststructuralism groups, are basically in the form of narration or discourse.

According to Suwondo (2011), A.J. Greimas is a French researcher who is adhered to structural theories. Like Propp, Levi-Strauss, Bremond, and Todorov, Greimas also developed his theory based on structural analogies in linguistics originating from Saussure. By looking for a structural analogy in linguistics Greimas applied his theory in fairy tales or Russian folk tales.

The narratology theory of A.J. Greimas is a refinement of Vladimir Propp's structuralism theory (Selden, 1991). Suwondo (2011) stated that the one who initially developed a structural theory based on fairy tale research was Vladimir Propp as seen in his book Morphology of the Folk Tale (in Russian). Which was later translated by Noriah Taslim into the Morphology of Folk Stories (1987). In the book, Vladimir Propp examined the structures of the story by assuming that the story structures are analogous to the syntactic structures that have the basic construction of the subject and predicate.

Algirdas Julien Greimas is a follower of structural flow from France who later developed the narrative theory of Vladimir Propp. Based on this theory Greimas then developed the narrative structuralism theory. Greimas introduced the concept of actant as the smallest narrative unit in literary works (Rokhmansyah, 2014). According to Greimas actant is something abstract like love, freedom, or a group of characters who have certain functions (Jabrohim, 1996). A function is interpreted as a basic unit of the story that explains logical and meaningful actions in the form of narrations. Therefore, an actant scheme maintains the emphasis on the storyline as the most important energy that moves the story into the storyline with the most important episodes consisting of the beginning, complications, and completion (Ratna, 2006).

Greimas then offered three binary oppositions (three spheres of opposed) which consist of six functions that are known as an actant. Actants are abstract roles that can be performed by someone or some actors. Furthermore, Jabrohim (1996) said that the notion of actant is associated with a unit of narrative syntax. Which is a syntax element that has a function-certain functions. The function in question is a basic unit of the story that explains action, which is meaningful and forms a narration. Susanto (2012) explained that the actant and character are not similar, the actant can be in non-human form. The same idea is expressed by Eriyanto (2015: 98) that actant does not mean in a form of a human, actant can be an act. Actant which serves as binary opposition put into schemes as displayed in Fig. 1 (Suwondo, 2011; Jabrohim, 1996). The scheme formated analysis can be seen in Fig. 1.

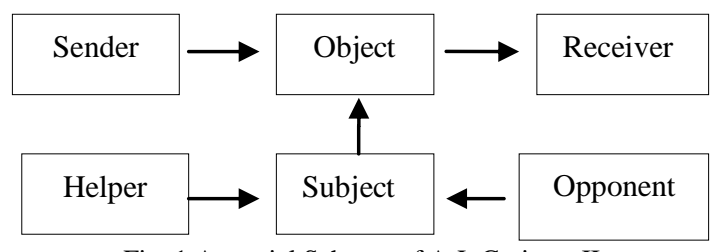

Fig. 1 Actantial Scheme of A.J. Greimas II

A sender is someone or something that is the source of ideas and functions as a driver of the story. This sender creates the desire for the subject to get the object. The object is someone or something that is desired, sought, or hunted by a hero on the sender's idea. Subject or hero is someone or something assigned by the sender to get the object wanted by the subject. Helper 'helper' is someone or something that helps or facilitates the efforts of the hero or subject in reaching the object. Opponent 'the challenger' is someone or something that hinders the efforts of a hero in searching for objects. Receivers someone or something that accepts the object hunted by the subject. In this regard, there is communication between the sender and the receiver. While there is a goal between the sender and the object there is a goal, and there is an agreement between the sender and the subject. There is an effort between the subject and the object, and there are a challenge and aids between the helper or opponent and subject. It is necessary to know that the actants in certain structures can occupy multiple functions depending on who occupies the function of the subject.

Greimas (Susanto, 2012) explained the meaning of six actants characters as follows: The sender is someone or something who desires the object. The subject is someone or something that the sender uses as a tool to get the object. While an object is someone or something wanted or desired by the sender through the subject. A helper is someone or something that comes to help the subject in carrying out his duties in achieving the object. The opponent is someone or something that comes in the way of obstructing the activities of the subject in reaching the object. The recipient is someone or something that receives the work of the subject in getting an object, sometimes the recipient is the sender himself.

A character can occupy several functions and roles in an actant scheme. In one actant scheme, sometimes not all of the actan functions are filled. Sometimes the helper act or opposing actant does not appear in the story structure (Busyrah, 2012). The other four actants, namely the sender, receiver, subject, and object are always found in the structure of a story.

Zaimar (Suwondo, 2011) explained that in addition to showing an actant scheme as a concept of the epistemology of structuralism, Greimas also suggests a story model that remained as a plot. The model is built by various acts called 
functions. The model which is then called a functional model, according to him, has a fixed way of working because indeed a story always moves from the initial situation to the final situation. The functional model has a task to describe the task of the subject to carry out the tasks assigned by the sender or sender found in actant. As mentioned previously that the functional model has a fixed working way because indeed a story always moves from the initial situation to the final situation. While the functional operation is divided into three stages as shown in Table I.

TABLE I

FUNCTIONAL MODEL OPERATIONAL A.J. GREIMAS

\begin{tabular}{ccccc}
\hline \multirow{2}{*}{ I } & \multicolumn{3}{c}{ II } & \multirow{2}{*}{ III } \\
\cline { 2 - 3 } & \multicolumn{2}{c}{ TRANSFORMATION } & \\
\hline Initial & Test & Main & Glory & Final \\
Situation & Stage & Stage & Stage & Situation \\
\hline
\end{tabular}

The first part is called the initial situation. In this section, the story begins with the statement that there is a desire to get something. In here there are calls, orders, or approvals. According to Busyrah (2012: 11), the initial situation is the initial part of the story that contains a statement about someone or something who is wanted or desired or as the purpose of the subject. This stage is usually characterized by the occurrence of the sender who becomes the intention or the power in the story.

The second part is the trans-formation section which includes: (1) the skill stage, that is the departure of the subject or hero, the emergence of opponents and helpers, and if the hero is unable to overcome the challenges he will be disqualified as a hero; (2) The main stage, namely the shift of space and time, in the sense that the hero has succeeded in overcoming challenges and travelling again. According to Busyrah (2012: 12), the main stage is the stage where the subject is successful in getting the target object. The transformation will stop at the main stage if there is no second challenge in the next event which hinders the process of submitting the subject's searched object to the receiver. If the submission process encounters obstacles, but succeeds in overcoming them, the glory stage is achieved. (3) The glory stage is the arrival of a hero. The same thought was raised by Zaimar (2011: 79) that the stage of glory is the stage of the arrival of heroes, the existence of original heroes, the uncovering of fake heroes, punishments for fake heroes, and services for genuine heroes. The third part is the final part of the situation. In this part, the object has been obtained and received by the receiver. The balance has occurred, the end of a desire for something at the same time ends the story.

\section{METHODOLOGY}

The method used in this research was descriptive. This research data was obtained through an in-depth study of documents available in the form of folk tales. Data in descriptive research according to Moleong (2014: 11) are in the forms of words, images, and not numbers.

The form of this research was qualitative, which is the form of research that prioritizes the process or procedure carried out, while the results depend on the research process itself. The approach used in this study was structural (objective) which is based on an Actantial study of A.J. Greimas.

The techniques of collecting data in this study were the documentary study technique. The use of the technique was based on the utilization of documents in a form of a story text of $N e^{\prime}$ Baruakng Kulup which has been recorded and has been already in a form of a printed document.

Tools for collecting data in this study were the researchers themselves. This is based on a belief that in a qualitative study the one who serves as the instrument is the researcher himself or herself. The qualitative study makes humans as the tools (instruments), meaning in the qualitative research (the researcher or with the help of other parties) acts as the instrument or main tool in both collecting data, recording the data, and interpreting the data by pouring all intellectual capability and knowledge, as well as the skills owned regarding the existing the phenomena (Bogdan and Biklen, Lincoln Guba in Moleong, 2014: 4-8). To facilitate data collection the researchers used equipment namely cards to record data. The tools used by researchers are intended to facilitate researchers to collect data so that the data taken is complete and based on facts. Therefore, the card used to record data is called a tool.

The data source in this study was the story-texts of $\mathrm{Ne}$ Baruakng Kulup, Dayak Kanayatn oral literature edited and translated into Indonesian and already in document form. The data of this study was in a form of a series of events which were in the forms of actants and functional structures that built the narrative structure of the story of $\mathrm{Ne}^{\prime}$ Baruakng Kulup.

The validity of the data testing technique used in this study was the persistence of observation and the investigator's triangulation. Which is a technique of checking the accuracy of data by maximizing the sharpness of the research team in conducting data analysis.

The researchers used structural approaches to analyze the narrative structures that built the story-text of $\mathrm{Ne}$ 'Baruakng Kulup. The implementation of the structural study work procedure was carried out through these following stages.

1. Carefully read the text of $N e^{\prime}$ Baruakng Kulup story which was set as the object of the study.

2. Identifying and classifying the actants that build the narrative structure of $N e^{\prime}$ Baruakng Kulup Story text.

3. Identifying and classifying the functions that build the narrative structure of $\mathrm{Ne}^{\prime}$ Baruakng Kulup Story text.

4. Analyzing and interpreting the actants that build the structure of the narrative text of $\mathrm{Ne}$ 'Baruakng Kulup story based on A.J. Greimas' Actantial scheme.

5. Analyzing and interpreting the functions that build the structure of the narrative text of $\mathrm{Ne}$ 'Baruakng Kulup story based on A.J. Greimas' Actantial scheme.

6. Concluding the results of the analysis and the results of the interpretation of the narrative structure of $\mathrm{Ne}$ ' Baruakng Kulup story based on the A.J. Greimas actantial scheme. 


\section{RESULTS AND DISCUSSION}

A. Results

\section{1) The Analysis of Actantial Scheme}

Fig. 2 is an analysis of the sixth actantial scheme in the story of $\mathrm{Ne}^{\prime}$ Baruakng Kulup.

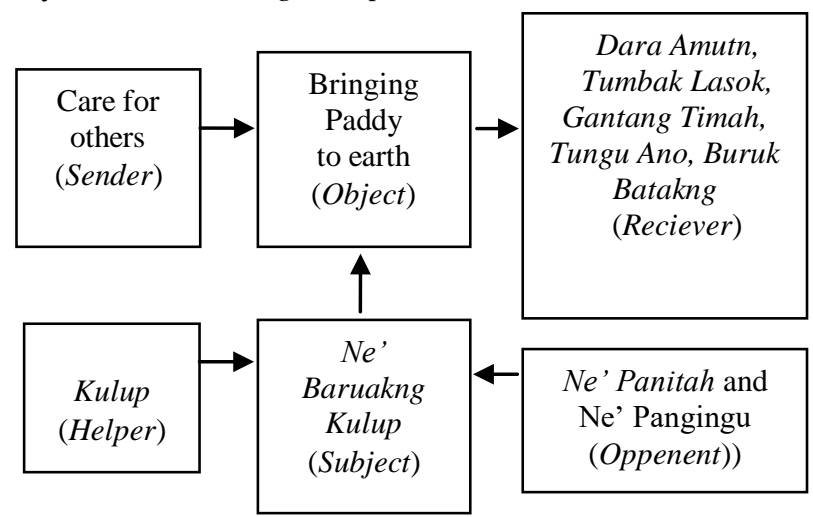

Fig. 2 The Sixth Actantial Scheme in The Ne' Baruakng Kulup Story

The idea of the story (sender) in the sixth Actantial scheme is an attitude of caring for others based on the spirit of sharing. Various ways were done by Ne' Baruakng Kulup (subject) to be able to bring paddy seeds to earth. However, he was always failed because it was known by both parents. $\mathrm{Ne}^{\prime}$ Ja'ek and $\mathrm{Ne}^{\prime}$ Pangingu (opponent) did not allow $\mathrm{Ne}$ ' Baruakng Kulup to bring paddy seeds to earth because of the resentment felt by $N e^{\prime} J_{a}^{\prime}$ 'ek towards his ex-wife who had expelled him and humiliated himself when he migrated to earth. This was because $\mathrm{Ne}^{\prime} \mathrm{Ja}^{\prime} \mathrm{ek}$ preferred to save two stalks of paddy from rats and sparrows rather than Mengayau, hunting a head of enemies. The feeling of heartache caused a grudge in $N e^{\prime} \mathrm{Ja}^{\prime} e k^{\prime}$ s heart so that he did not want to share paddy with humans. Please, take a look at these following quotes.

"Okay, you can go down but don't bring paddy seeds. Your ancestors also forbade us carrying the paddy seeds. We don't want that paddy seedlings go down to the earth, "said Ne' Ja'ek (NBK, lines 246-248).

"Hah! Look at that, Baruakng! Are you bringing paddy seeds? I (Father) have said no. Do not! If you dare to bring it, I (Father) will kill you. Come on, return the paddy seedlings to the barn, "said $\mathrm{Ne}^{\prime} \mathrm{Ja}$ 'ek angrily (NBK, lines 409-411).

At the end of Baruakng (subject) found a way to bring paddy seeds to earth after three failures because his father knew his plans. Baruakng at the end managed to bring the paddy seeds (object) by hiding the rice seedlings at the tip of his genital or Kulup (foreskin). In this case, the Kulup or foreskin acts as a helper. His new effort was not in vain, he then handed over the paddy seeds to Dara Amutn and his half-brothers. Consider the following quote.

The next day, Baruakng cautiously took his provision and favourite Gasing or spinning-top toy. The Paddy seeds that he had taken from the Paddy Dango or barn were hidden in the chamber. Then slowly put it into the hole of his genital. After entering seven rice seeds, which consisted of four-morning seeds (Sunguh) and three padd seeds (Pulut) into the folds of his genitals, Baruakng then met his father and mother to tell them that he was really departing to earth. Seeing that his child only brought supplies and a top, his parents were not suspicious at all (NBK, lines 494-501).

The spirit of sharing and caring for humans is the basic thing that encourages Baruakng to put himself at risk for bringing paddy seeds to the earth so that humans have basic food like those of Kayangan (heaven) humans.

\section{2) The Analysis of the Functional Model}

a. Initial Situation

The sixth actant scheme begins with the desire of Dara Amutn to meet with her children's playmates named Baruakng. After meeting, Dara Amutn later realized that Baruakng was the child of her ex-husband, $\mathrm{Ne}^{\prime} \mathrm{Jaek}$, who had been expelled because of not being able to get a Kayau head. Dara Amutn then told Baruakng that she was a former wife of $N e^{\prime}$ Jaek and Baruakng's playmates are Baruakng's half-brothers. This situation made Baruakng got closer to them and considered them his family, as illustrated in these following quotes.

"Son, who are you actually, and where are you from? Who are your parents?" asked the mother of four. "I am from Kayangan, Ma'am. My father is Ja'ek, and my mother is Pangingu," said Ne'Baruakng.

"Who? Your father is Ja'ek?"Asked the mother of four children in surprise. "Right, Ma'am!" responded $\mathrm{Ne}$ ' Baruakng. If so, this boy is the son of my exhusband, the woman muttered to herself (NBK, lines 377-385).

"Thank goodness, you do not disagree with each other while playing Gasikng or top. These are your brothers and sisters. "Tumbak Lasok, Tungu Ano, Gantang Timah and you are Buruk Batakng, this Baruakng is the son of your missing father," Dara Amutn explained to her four children. "Baruakng, Now, these four siblings are your brothers and sisters from your father when your father was still my husband" continued Dara Amutn to Ne' Baruakng. $\mathrm{Ne}$ 'Baruakng and the four siblings were shocked. They never expected that they are actually halfsiblings. Dara Amutn then recounted the incident happening to her when she was still with her husband, $N e^{\prime} J^{\prime} e k$ in the past. She did not feel tears run down her cheeks. Dara Amutn wept bitterly (NBK, lines 391-400).

\section{b. Transformation}

1) Skills Stage

Baruakng's heart was moved when Dara Amutn asked him to bring paddy seeds to earth. A sense of solidarity and kinship were growing. He at the end intended to bring his stepmother and half-brothers to paddy seeds. The intention was so strong that he ignored his father's message forbidding 
him to bring paddy seeds to earth. Baruakng agreed with Dara Amutn's request. Please consider the following quote. "Baruakng, bring us paddy seeds, just like what I just ate," asked Dara Amutn. Ne' Baruakng Just nodded showing an agreement (NBK, lines 401-402).

\section{2) Main Stage}

Baruakng tried various ways to be able to bring rice seeds to earth. Initially, he put all the rice seeds in his grasp, but when bidding farewell to his father, the glow of paddy in his grasp was seen by his father. Baruakng was scolded by his father right away. His father threatened to kill him if he dared to bring paddy seeds to earth. Consider the following quote.

The day after tomorrow when $N e$ 'Baruakng was going to go back down to earth, he did not forget to grasp a handful of paddy seeds to bring along with him. However, when he was about to say goodbye, the paddy seeds inside his grasp was blinking. Begging the truth from his father, the paddy seeds in his grip blinked in yellowish light and seen by his father "Hah! Look at that! How come Baruakng! Do you want to bring paddy seeds? I have said no. Do not! If you dare to take it, I will kill you. Come on, put the rice seedlings back in the barn", said $\mathrm{Ne}^{\prime} \mathrm{Ja}^{\prime} \mathrm{ek}$. Seeing his father angry, then Ne 'Baruakng hurried to return the paddy to the barn. $N e^{\prime}$ Baruakng felt sad because he had not managed to bring the paddy to his brothers on earth. Sadly, Ne' Baruakng cancelled his intention that day to go down to earth (NBK, lines 404-414).

Because the effort was unsuccessful, Baruakng tried to hide the paddy seeds inside the folds of his pants. That was also known by his father. Once again, his father threatened Baruakng if he dared to bring paddy seeds to earth. See the following quote.

On the fourth morning, as he promised to his big brothers $\mathrm{Ne}$ 'Baruakng intended to go down to the earth. He prepared his supply and his top-toy. He hid the Paddy he stole from the barn inside the folds of his kapoa'. Ne' Baruakng met his parents to ask their permission to leave. However, before he left, his father had found out how Baruakng hid the paddy seeds. "Open the folds of your kapoa'!" commanded his father. With no choice, Ne' Baruakng opens the folds of his kapoa'. "See, I have warned you, but still you wanted to bring the paddy seeds to the earth," said $N e$ ' Ja'ek angrily. "They asked me to bring them Paddy seeds." Ne' Baruakng responded softly. "No!," banned Ne' Ja'ek harshly. "But...but they are also your children!" Ne' Baruakng said in shuttered. $\mathrm{Ne}$ ' Ja'ek and Ne' Pangingu were shocked. "Even if your Father's children, never let them know paddy, "said $\mathrm{Ne}$ ' Pangingu after relieving her surprise. $\mathrm{Ne}$ ' Baruakng just looked down silently, he did not want to answer again. He then passed and his parents were still angry (NBK, lines 451-465)

Baruakng did not feel despairement, he then put the paddy seeds into his mouth. When saying goodbye, the seeds in his mouth scattered out when his father asked him. Consider the following quote.

"Baruakng, come here! What is inside your mouth?" Asked his father harshly. "Paaaaaddy!" responded $N e$ ' Baruakng stammering. He then released the paddy from his mouth. "I want to feed chicken, Daddy," Ne'Baruakng dodged. The paddy inside his mouth was dissipated to the chickens nearby. "Uhhh I failed again," he thought (NBK, lines 466-474).

\section{3) Glory Stage}

After failing to bring paddy to the earth many times, Baruakng finally found a way so that the paddy he brought was invisible to his father. It also happened that Baruakng had not been circumcised, so the rice seeds were inserted into the hole of his genital and covered by his foreskin. In this way, finally, Baruakng can bring seven paddy seeds to earth. Consider the following quote.

The next day, Baruakng cautiously took his supply and favourite top toy. The paddy seeds that he had taken from the Paddy barn or Dango were hidden in the chamber. Then slowly he put it into the hole of his genital, hiding inside his genital foreskin. After entering seven rice seeds, consisting of four morning of Sunguh Paddy seeds into the hole of his genital, and three Pulut paddy seeds inside the folds of his genital skin. Baruakng met his parents and asked for permission to depart. Seeing their son only brought his food supply and a top toy, his parents were not suspicious at all. The paddy that usually looked glittering was not seen at all in Baruakng's folds, especially they were protected by his Kapoa' cloth. With confident steps, Baruakng ascended the earth. His face looked happy as he was able to trick the eyes of his both parents (NBK, line 493-503).

\section{c. Final Situation}

The success of Baruakng to bring paddy to the earth made Dara Amutn and her children happy. In the Actant 6 scheme, it is shown that Baruakng (subject) succeeded in defeating the holder, namely his mother and father. Consider the following quote.

Arriving on earth, Tumbak Lasok and his younger siblings, who had been waiting for his arrival, approached Baruakng. "How is it little brother Baruakng, Successful?" asked Tumbak Lasok anxiously. "It's here!" said Baruakng smilingly. "Here you are!" said he while taking out the seeds from his genital with no feeling of embarrassment $\mathrm{He}$ then gave the seeds to Tumbak Lasok. Seeing the way $N e$ ' Baruakng hid the paddy seeds, his four big brothers smiled at him. Once they got the seeds, they asked promptly to meet their mother. "Mom, mom!" Tumbak Lasok called his mother, Dara Amutn. "What's up? Oh, you Baruakng!" said Dara Amutn in surprised realizing Baruakng was there. "He successfully brought us the paddy seeds, mom" said Tumbak Lasok while handing the paddy seeds to his mom. Dara Amutn was so happy when seeing 
Baruakng success although she did not know yet how he did it. (NBK, lines 504-515).

\section{B. Discussion}

Referring to previous research conducted by Salahuddin and Nensilianti (2017) conclude that Maryamah Karpov novel has 11 actantial schemes and 11 functional models caused by 11 conflicts. In the novel's storyline, Ikal is the dominant figure acting as a subject or hero is shown in actant schemes in conflicts II, IX, X, and XI. Thus, the researchers suggest that more research be conducted using the Narratology Theory of A.J Greimas since such kind of research is still very limited in number.

Likewise, the analysis of the Ne' Baruakng Kulup story resulted in 14 actan schemes and 14 functional models. In the story, Baruakng Kulup is the dominant figure and a hero in the storyline. He is as subject in the actant scheme of the fifth, sixth, eighth, ninth, tenth, and fourteenth actan.

Suwondo (1994) stated that the storyline of Danawa Sari Putri Raja Giant (1963) is very complex because it found four patterns structures in which each elemental function can be traced separately. However, although there are four structural patterns, which form the framework the main story is pattern II structure, while the other three patterns are only is a side plot.

In this study, the main actant of the 14 actant schemes is the sixth Actant scheme because the main core of $\mathrm{Ne}^{\prime}$ Baruakng Kulup story recounts the process of his ascending the earth. In the sixth scheme, it is told how Baruakng has managed to bring seven paddy seeds to the earth, namely 4 ordinary paddy seeds, and 3 pulut or sticky paddy seeds. This was done for his solidarity with his stepbrothers. The paddy seeds were then handed over to Dara Amutn, Tumbak Lasok, Gantang Timah, Buruk Batakng, and Tungu Ano. This action caused Baruakng to lose the opportunity to be circumcised. This condition caused him to be called the Baruakng Kulup (foreskin). The first to fifth actantial scheme tells the story of the events before paddy seeds were brought to the earth, while from the seventh to fourteenth of actantial scheme tells the life of Baruakng Kulup after taking the paddy to earth.

Januarsyah (2017) concluded that the actant scheme in the folk tales of Roro Jonggrang can be produced based on four perspectives of characters who occupy the role of subject actors, namely: (1) Roro Jonggrang; (2) Bandung Bondowoso; (3) Prambanan Society; and (4) Jin. Then, the tradition of hitting a pestle on a mortar is a myth found in the folk tale of Roro Jonggrang. Referring to the article, the scheme of the actant in the story Ne 'Baruakng Kulup.

Referring to the article, the actant scheme of the $\mathrm{Ne}$, Baruakng Kulup story can be generated based on the six perspectives of the characters who occupy the role of the subject, namely: (1) Baruakng Kulup; (2) Ne' Jaek; (3) Ne' Panitah and Ne' Pangadu; (4) Jumawar Patih Ampor Gayokng; (5) Shaman Baliatn; and (6) Beautiful Ghost. The origin of the paddy descent to the earth brought by $\mathrm{Ne}$, Baruakng Kulup is still commemorated as a tradition called naik dango which is interpreted as a thanksgiving for the paddy harvest they got while farming that year.

The subject of the hero in the Ne' Baruakng Kulup story is Baruakng Kulup who occurs in the sixth actantial scheme and sixth functional structures, namely $5^{\text {th }}, 6^{\text {th }}, 8^{\text {th }}, 9^{\text {th }}, 10^{\text {th }}$, $14^{\text {th }}$. From the 14 actantial schemes and 14 functional structures, there are 10 actantial schemes and 10 functional structure that are not perfect since they do not have an opponent element. They are actantial schemes and functional structures $1^{\text {st }}, 2^{\text {nd }}, 4^{\text {th }}, 8^{\text {th }}, 9^{\text {th }}, 10^{\text {th }}, 11^{\text {th }}, 12^{\text {th }}, 13^{\text {th }}$, and $14^{\text {th }}$. There are 4 actantial schemes and functional structures that are perfect, such as $3^{\text {rd }}, 5^{\text {th }}, 6^{\text {th }}$, and $7^{\text {th }}$. Actant schemes and functional structures correlate to each other following their order or sequence. Each component existing in the actant has a clear role in stages found in the functional structures.

\section{CONCLUSIONS}

\section{A. Conclusions}

Based on the results of the analysis, the following conclusions can be drawn. 14 actant schemes and 14 functional structures are found in the story of $\mathrm{Ne}$ 'Baruakng Kulup. Interpretation of the correlation scheme of actant and functional structure produces the followings: the subject or hero in the story being analyzed is the figure of $\mathrm{Ne}$ Baruakng Kulup; the main actant scheme is in the sixth actantial scheme; and there are 4 actant schemes and 4 perfect functional structures, namely the actant schemes and functional structures number $3^{\text {rd }}, 5^{\text {th }}, 6^{\text {th }}, 7^{\text {th }}$. While imperfect numbers are $1^{\text {st }}, 2^{\text {nd }}, 4^{\text {th }}, 8^{\text {th }}, 9^{\text {th }}, 10^{\text {th }}, 11^{\text {th }}, 12^{\text {th }}, 13^{\text {th }}$, and $14^{\text {th }}$.

Actant schemes and functional structures are interrelated with each other following their sequences. Each commissioner in the actant scheme is increasingly clear in its role in the stages existing in the functional structures.

\section{B. Suggestions}

1. Actantial Study based on A.J. Greimas can be used to analyze other prose texts such as romance, novels, and short story collections.

2. This study model can be used to foster and develop research workshops for students taking courses in Literature Research Methodology, Regional Literature, Literature Sociology, Comparative Literature, and Prose Studies.

3. Further studies on other Dayak Kanayatn folktales are open to being conducted by utilizing a variety of sources available in the community.

\section{REFERENCES}

Brundvand, Jan Harold. (1968). The Study of American Folklore-An Introduction. New York: W.W. Norton 7 Co. Inc.

Busyrah, Hamidah. (2012). Model Aktansial dan Fungsional Greimas pada Sepuluh Cerkak dalam Antologi Geguritan Lan Cerkak Pisungsung. Skripsi. Depok: Universitas Indonesia. 
Dorson, R.M. (Ed.). (1968). Peasant Customs and Savage Myths. London: Routledge and Kegan Paul.

Dundes, A. (1965). The Study of Folklore. Englewood Cliff, New Jersey: Prentice Hall, Inc,

Eliade, M. (1964). Myth and Reality. London: George Allen \& Unwin Ltd.

Emzir and Rohman, Saifur. (2016). Teori dan Pengajaran Sastra. Jakarta: Rajawali Pers. PT Raja Grafindo Persada.

Eriyanto. (2015). Analisis Naratif: Dasar-Dasar dan Penerapannya dalam Analisis Teks Berita Media. Jakarta: Kencana Prenada Media Group.

Escarpit, Robert. (2005). Sosiologi Sastra. Jakarta: Yayasan Obor Indonesia.

Hutomo, Suripan Sadi. (1991). Mutiara yang Terlupakan Pengantar Studi Sastra Lisan. Surabaya: HISKIKomisariat Jawa Timur.

Jabrohim. (1996). Pasar dalam Perspektif Greimas. Yogyakarta: Pustaka Pelajar.

Januarsyah, Gilang. (2017). Penerapan Model Aktansial Greimas dalam Cerita Rakyat Roro Jonggrang: Satu Kajian Semiotik Naratif. (online). http://www.academia.edu/35915674/penerapan_mo del_aktansial_greimas_dalam_cerita_rakyat_roro_j onggrang_satu_kajian_semiotik_naratif). 1-5. (Accessed on October 24, 2020).

Krohn, K. (1971). Folklore and Methodology. Austin \& London: The University of Texas.

Luxemburg, Jan van, Mieke Bal, and Willem G. Weststeijn. (2009). Pengantar Ilmu Sastra. Jakarta: PT Gramedia Pustaka Utama.

Moleong, Lexy J. (2014). Metode Penelitian Kualitatif Edisi Revisi. Bandung: Remaja Rosda Karya.

Ratna, Nyoman Kutha. (2006). Penelitian Sastra. Yogyakarta: Pustaka Pelajar.

Rokhmansyah, Alfian. (2014). Studi dan Pengkajian Sastra. Yogyakarta: Graha Ilmu.

Salahuddin, Nurfadhilah., and Nensilianti (2017). Skema Aktan dan Model Fungsional Novel Maryamah Karpov: Kajian Naratologi A.J.Greimas. (Online). https://www.academia.edu/35123906/artikel_skema _aktan_dan_model_fungsional.docx). 1-17. (Accessed on October 18, 2020).

Sehandi, Yohanes. (2014). Mengenal 25 Teori Sastra. Yogyakarta: Penerbit Ombak Tiga.

Selden, Raman. (1991). Panduan Pembaca Teori Sastra Masa Kini. Terjemahan Rachmat Djoko Pradopo. Yogyakarta: Gadjah Mada University Press.

Susanto, Dwi. (2012). Pengantar Teori Sastra (Dasar-Dasar Memahami Fenomena Kesusastraan: Psikoanalisis Sastra, Strukturalisme, Formalisme Rusia, Marxisme, Interpretasi dan Pembaca, dan Pascastrukturalisme). Yogyakarta: CAPS

Suwondo, Tirto. (1994). Analisis Struktural Danawa Sari Putri Raja Raksasa Penerapan Teori A.J. Greimas. Jurnal Widyaparwa, 43, 1-17.
Suwondo, Tirto. (2011). Studi Sastra (Konsep Dasar Teori dan Penerapannya pada Karya Sastra. Yogyakarta: Gama Media. 